
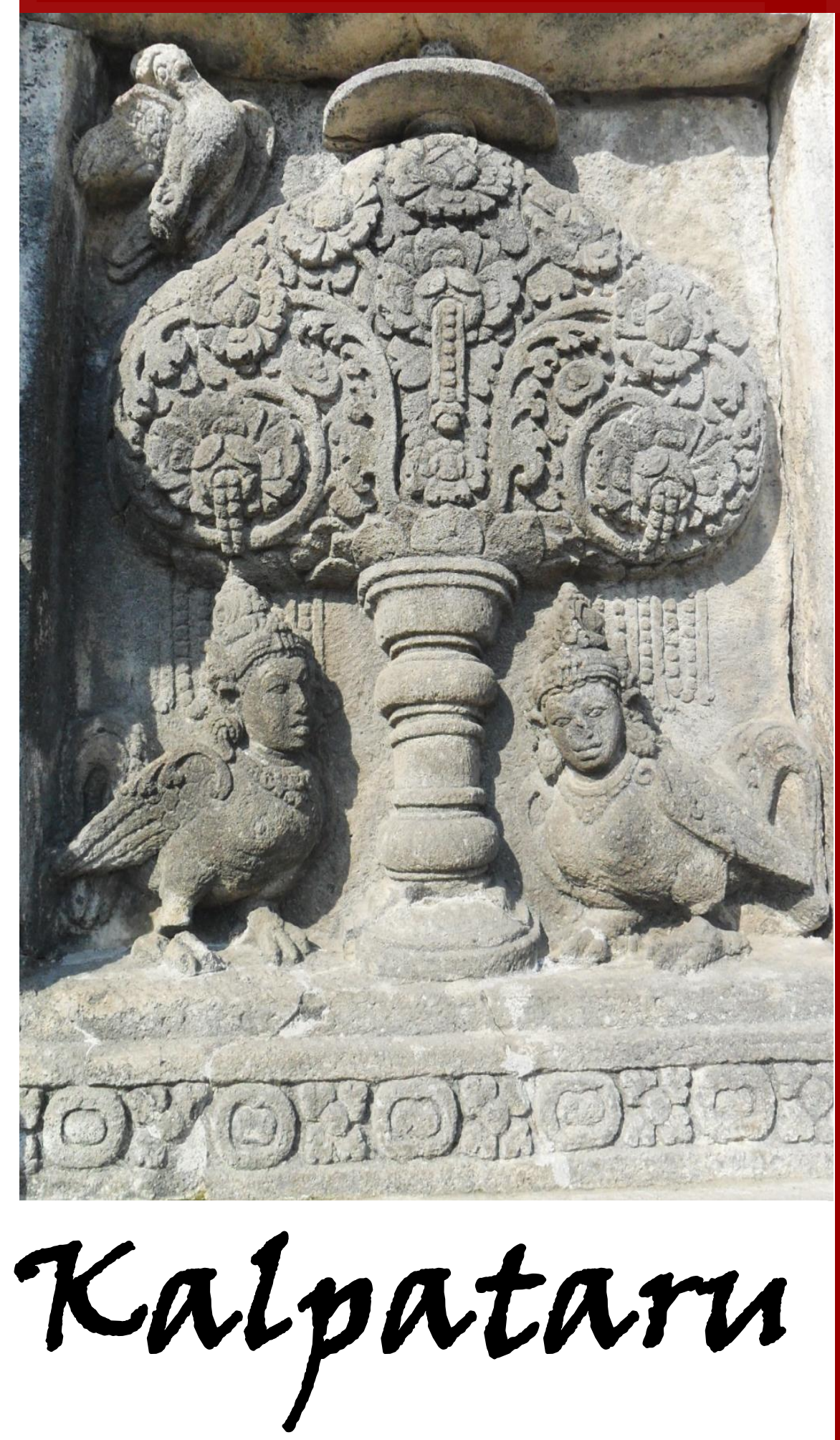

JURNAL SEJARAH DAN PEMBELAJARAN SEJARAH

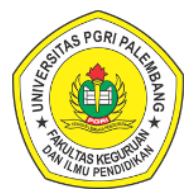

Program Studi Pendidikan Sejarah Jurusan Pendidikan IPS

Fakultas Keguruan dan IImu Pendidikan Universitas Persatuan Guru Republik Indonesia Palembang
Pengaruh Penerapan Model Project Based Learning Berbasis Video Vlog Dalam Proses Pembelajaran Sejarah Farena Adela, Nur Ahyani, Dina Sri Nindiati

Identifikasi Nilai Pedagogi Pada Pahatan Monolid Desa Jarakan Sebagai Sumber Pembelaran Sejarah Alzata Putra, Sukardi, Aan Suriadi

Nilai Sejarah Makam Puyang Ulak Laut di Pecah Pinggan Sebagai Sumber Pembelajaran Sejarah Berbasis Digital Dewi Cahya, Sukardi, Eva Dina Chairunisa

Pola Sebaran Permukiman di Kota Kayu Agung

I Made Lingga Wardana, Sukardi, Wandiyo

Peran Adam Malik Sebagai Ketua Sidang Majelis Umum PBB 1971 Rani Noviyanti

Pemanfaatan Foto dan Arsip Sebagai Sumber Pembelajaran Sejarah Riki Andi Saputro, Muhammad Fitri

Nilai-Nilai Sejarah Puyang Muara Rambang Sebagai Sumber Pelajaran Sejarah Lokal di SMA 01 Muarakuang Dwi Cahyati, Sukardi, Eva Dina Chairunisa

Pemikiran Abdul Mukti Ali Sebagai Sumber Pembelajaran Sejarah di SMA Patra Mandiri 1 Palembang Andika Merryanto Saputra, Aan Suriadi, Ahmad Zamhari

Perjuangan Hj. Rangkayo Rasuna Said Sebagai Pejuang Politik dan Pemikir Pergerakan Pada Masa Pra Kemerdekaan

Narani Agesti, Ageng Sanjaya

Nilai Sosial Religi Tradisi Manopeng Pada Masyarakat Banyiur Muhammad Fitri, Heri Susanto 


\title{
NILAI-NILAI SEJARAH PUYANG MUARA RAMBANG SEBAGAI SUMBER PELAJARAN SEJARAH LOKAL DI SMA 01 MUARAKUANG
}

\author{
Dwi Cahyati \\ Mahasiswa Program Studi Pendidikan Sejarah FKIP Universitas PGRI Palembang \\ Email: dwicahyati297@gmail.com \\ Sukardi \\ Dosen Program Studi Pendidikan Sejarah FKIP Universitas PGRI Palembang \\ Email: sukardi_sj@univpgri_palembang.ac.id \\ Eva Dina Chairunisa \\ Dosen Program Studi Pendidikan Sejarah FKIP Universitas PGRI Palembang \\ Email: evadinach19@gmail.com
}

\begin{abstract}
ABSTRAK
Puyang Muara Rambang adalah sosok yang hampir tidak pernah kalah dalam segi apapun (mengalahkan dirinya dan orang lain), kesaktian dan keajaiban yang dimilikinya sangat disegani oleh pengikutnya maupun musuh-musuhnya. Rumusan masalah dalam penelitian ini adalah bagaimana nilainilai sejarah Puyang Muara Rambang sebagai sumber belajar sejarah lokal di SMA Negeri 01 Muarakuang? Tujuan penelitian ini adalah untuk mengetahui nilai-nilai sejarah Puyang Muara Rambang sebagai sumber belajar sejarah lokal di SMA Negeri 01 Muarakuang. Metode penelitian yang digunakan deskriptif kualitatif. Teknik pengumpulan data dalam penelitian ini adalah wawancara, observasi, dokumentasi dan studi pustaka. Teknik analisis data dalam penelitian ini adalah reduksi data, penyajian data dan penarikan kesimpulan. Berdasarkan hasil penelitian nilai-nilai sejarah yang terdapat pada rumah Limas Seratus Tiang, adalah: nilai sosial, nilai estetika dan nilai relegius. Dengan dijadikannya nilai-nilai Puyang Muara Rambang sebagai sumber pembelajaran sejarah lokal, maka dapat membantu siswa mengetahui sejarah lokal sehingga dapat menumbuhkan rasa nasionalisme dalam diri siswa.
\end{abstract}

Kata Kunci: Nilai-nilai Sejarah, Puyang Muara Rambang, Sejarah Lokal

\section{A. PENDAHULUAN}

Kabupaten Ogan Ilir merupakan salah satu kabupaten di Provinsi Sumatera Selatan. Di wilayah Kabupaten Ogan Ilir banyak ditemukan nilai-nilai sejarah yang masih melekat dan sering dibicarakan dalam masyarakat. Nilai-nilai sejarah disebarkan melalui tutur kata dari mulut kemulut atau suatu dengan contoh yang disertai dengan gerak isyarat dan alat pembantu pengingat dari satu generasi ke generasi selanjutnya. Sifat cerita rakyat adalah anonim, yakni nama penciptanya sudah tidak diketahui lagi. Salah satu cerita rakyat yang ada di Kabupaten Ogan Ilir yaitu nilai-nilai sejarah Puyang Muara Rambang.

Berdasarkan hasil wawancara peneliti yang dilaksanakan pada bulan Januari 2021 kepada beberapa warga di Desa Lubuk Keliat
Kecamatan Lubuk Keliat Kabupaten Ogan Ilir, diperoleh informasi bahwa: 1) Puyang Muara Rambang adalah sosok yang hampir tidak pernah kalah dalam segi apapun (mengalahkan dirinya dan orang lain), kesaktian dan keajaiban yang dimilikinya sangat disegani oleh pengikutnya maupun musuh-musuhnya; 2) Puyang Muara Rambang adalah sosok seorang yang baik hati, bukan hanya kepada manusia tetapi ke makhluk lain juga, seperti hewan dan tumbuh-tumbuhan.

Dari informasi yang telah diuraikan, sehingga nilai-nilai sejarah Puyang Muara Rambang pada saat ini masih cukup eksis keberadaannya, karena masih mendapat dukungan dari masyarakat. Hal ini dikarenakan, banyak nilai-nilai yang terkandung yang ada pada Puyang Muara Rambang. Dengan 
demikian, nilai-nilai sejarah yang ada pada Puyang Muara Rambang memiliki peranan penting bagi dunia pendidikan khususnya di sekolah terutama pada mata pelajaran sejarah. Disisi lain, nilai-nilai juga merupakan aset berharga yang mungkin tidak dimiliki oleh wilayah lain bahkan negara lain. Penemuan nilai-nilai sejarah yang terdapat pada Puyang Muara Rambang diharapkan juga dapat menambah wawasan pengetahuan edukasi bagi siswa-siswi ditingkat persekolahan. Seperti yang terjadi dalam pembelajaran sejarah di sekolah, bahwa di antara tujuan pendidikan yaitu kepribadian atau pembentukan watak.

Mempelajari sejarah akan memperoleh empat kegunaan, yaitu guna rekreatif, guna inspiratif, guna instruktif, dan guna edukatif. Lebih lanjut, peristiwa di masa lampau yang diangkat kembali melalui prosedur penelitian sejarah oleh ahli dianggap memiliki manfaat atau kegunaan bagi kehidupan manusia pada masa sekarang yang mempelajarinya, antara lain untuk pendidikan, memberi pengajaran (instruktif), memberi ilham (inspiratif), memberi kesenangan (rekreatif) (Wasino, 2007:10). Menurut Kartodirjo (2014:2) menjelaskan bahwa kesadaran akan nilai-nilai sejarah terhadap sesuatu mengandung arti sadar akan apa yang diamati dan sadar terhadap proses pengamatanya.

Pengetahuan sejarah yang harus dimiliki siswa adalah peristiwa-peristiwa sejarah masa prasejarah hingga sekarang, baik itu sejarah di Indonesia maupun dunia. Pendapat lain dari L.B. Namier dalam Soedjatmoko (1995:368) bahwa, tujuan dari pendekatan historis adalah untuk memahami situasi-situasi, untuk mengkaji kecenderungan-kecenderungan, untuk mengetahui bagaimana sejumlah hal berjalan dan puncak pencapaian studi sejarah adalah kesadaran sejarah yang memuat suatu pemahaman intuitif mengenai bagaimana sejumlah hal tidak terjadi (bagaimana sejumlah hal terjadi merupakan masalah pengetahuan khusus). Sumber belajar sejarah sendiri dapat memotivasi siswa dan motivasinya untuk ingin lebih mengetahui tentang sejarah, salah satunya adalah sumber belajar dari nilai-nilai sejarah makam Puyang Muara Rambang di
Desa Lubuk Keliat Kecamatan Lubuk Keliat Kabupaten Ogan Ilir.

Melihat urgensi yang telah diuraikan, dirasakan penting untuk melakukan penelitian mengenai nilai-nilai sejarah puyang Muara Rambang. Dengan demikian, penelitian ini diharapkan dapat memberikan sebagai sumber belajar bagi para guru dalam proses pembelajaran. Berdasarkan latar belakang ini, peneliti tertarik untuk mengadakan penelitian dengan judul "Nilai-Nilai Sejarah Puyang Muara Rambang Sebagai Sumber Belajar Sejarah Lokal di SMA Negeri 01 Muarakuang".

\section{B. METODE PENELITIAN}

Metode penelitian ini adalah menggunakan metode penelitian deskriptif kualitatif. Penelitian deskriptif adalah salah satu jenis penelitian yang bertujuan untuk menyajikan gambaran lengkap mengenai sosial atau dimaksudkan untuk eksplorasi dan klarifikasi mengenai suatu fenomena atau kenyataan sosial dengan jalan mendeskripsikan sejumlah variabel yang berkenaan dengan masalah yang diteliti. Sedangkan penelitian kualitatif sebagai metode ilmiah sering digunakan dan dilaksanakan oleh sekelompok peneliti dalam bidang ilmu sosial, termasuk juga ilmu pendidikan. Sejumlah alasan juga dikemukakan yang intinya bahwa penelitian kualitatif memperkaya hasil penelitian kuantitaif. Penelitian kualitatif dilaksanakan untuk membangun pengetahuan melalui pemahaman dan penemuan (Sugiyono, 2005:25). Teknik pengumpulan data menggunakan wawancara dan dokumentasi. Subjek penelitian adalah makam Puyang Muara Rambang, masyakarakat desa dan kepala desa Lubuk Keliat Kecamatan Lubuk Keliat Kabupaten Ogan llir.

\section{HASIL DAN PEMBAHASAN}

Berdasarkan silsilah yang dibuat oleh Drs. H. Muhammad Aiman Fickry, tanggal 26 November 2000, bahwa Puyang Muara Rambang merupakan putra mahkota Kerajaan Sriwijaya. Beliau adalah anak dari Balaputradewa "Raja Kerajaan Sriwijaya".

Puyang Muara Rambang adalah sosok yang hampir tidak pernah kalah dalam segi 
apapun (mengalahkan dirinya dan orang lain), kesaktian dan keajaiban yang dimilikinya sangat disegani oleh pengikutnya maupun musuhmusuhnya. Selain itu, Puyang Muara Rambang adalah sosok seorang yang baik hati, bukan hanya kepada manusia tetapi ke makhluk lain juga, seperti hewan dan tumbuh-tumbuhan.

Puyang Muara Rambang ditempatkan menjadi generasi ke-2 (dua) dan mempunyai tujuh orang anak yaitu: Puyang Meruhum Sakti, Puyang Sake Sekemilung, Puyang Serunting Sakti, Puyang Penjalang Sakti, Puyang Rejingan Sakti, Puyang Rubiyah Inang Sakti, dan Puyang Atung Bungsu Sakti.

Puyang Muara Rambang wafat pada tahun 1788 Masehi, yang memiliki ukuran makam sebesar 2,5 meter (panjang) dan 1,5 meter (lebar) dan terletak di Desa Lubuk Keliat Kecamatan Lubuk Keliat, Kabupaten Ogan Ilir. Di daerah sekitar Makam Puyang Muara Rambang terdapat sungai. Sungai Rambang adalah sungai yang mengalir dari daerah perbukitan Muara Enim, menembus ke daerah Selatan Prabumulih dan mengalir sampai ke wilayah Kabupaten Ogan Ilir tepatnya terletak di dekat makam Puyang Muara Rambang di Desa Lubuk Keliat Kecamatan Lubuk Keliat, Kabupaten Ogan Ilir. Sungai ini mencitrakan bahasa dan suku Rambang, yang menggambarkan rata-rata orang yang mendiami di pinggir jalan aliran sungai ini adalah orang-orang Rambang atau orang yang memakai bahasa Rambang. Dengan mengetahui alur sungai ini, bisa juga untuk mengetahui alur sejarah peradaban orang Rambang, baik di Hilir maupun di Hulu sungai. Di dalam sungai ini, terdapat buaya besar yang berwarna hitam dan putih yang mendiami muara ini. Konon, panjang buaya ini tempak melintang penuh di aliran sungai. Beberapa masyakarat desa menjelaskan mereka memang pernah melihat buaya ini, namun katanya tak sembarang orang bisa melihat buaya ini. Menurut kepercayaan pengunjung, bila ada yang mampu melihat buaya itu timbul di muara sungai, maka sepulangnya dia akan memperoleh keberuntungan. Namun kepercayaan ini, menurut penulis bukannya harus dipercayai namun harus dibantah karena tidak sesuai dengan karakter ilmiah.
Nilai-nilai sejarah yang terdapat pada Puyang Muara Rambang ialah nilai relegius dan nilai sosial.

\section{Nilai Relegius}

Manusia sebagai cipataan Tuhan secara sadar memiliki hubungan individu antara manusia dengan penciptanya. Hubungan tersebut dapat dilakukan dengan berbagai cara baik melalui agama maupun berbagai pola kepercayaan yang selalu dipegang teguh dan melekat dalam kehidupan keseharian. Bentuk kepercayaan serta aktivitas masyarakat terhadap kubur Puyang Muara Rambang. Masyarakat Desa Lubuk Keliat hampir secara keseluruhan 99\% menganut agama Islam, sebagai wujud sakral masyarakat Desa Lubuk Keliat meyakini makam Puyang Muara Rambang sebagai makam yang mulia karena merupakan makam dari seorang wali Allah sehingga makam Puyang Muara Rambang dianggap sakral oleh masyarakat. Hal tersebut, sesuai teori sakral dan profan yang mengaggap bukan hanya wujud benda itu sendiri yang merupakan tanda dari sakral tetapi berbagai sikap dari manusia yang memperkuat kesakralan yang menghasilkan suatu aktivitas dan emosi keagamaan yang terwujud dalam tradisi ziarah makam puyang, berupa peraturan selama pengantian kelambu penutup makam Puyang Muara Rambang yang hanya dilakukan oleh pihak tertentu saja seperti: juru kunci, perwakilan dari keturunan Puyang Muara Rambang, dan setelah berziarah jika hendak keluar dari ruangan makam tidak boleh membelakangi kubur puyang.

Selain itu, pada saat berziarah masyarakat dari dalam dan luar Desa Lubuk Keliat harus membawa "suguhan" yang dipersembahkan untuk Puyang Muara Rambang. Inilah dasar timbulnya kepercayaan seperti masyarakat setempat bahwa kubur Puyang Muara Rambang merupakan makam leluhur mereka yang dianggap sebagai makam para wali yang memiliki kekuatan dan kelebihan berupa karamahnya dari berkat hidayah Allah SWT. Kepercayaan masyarakat Desa Lubuk Keliat terhadap kubur Puyang Muara Rambang ini muncul sejak dahulu. Menurut mereka bahwa keajaiban kubur puyang benar-benar nyata. Hal 
ini dibuktikan dengan berbagai cerita dan pengalaman masyarakat setempat atas leluhur mereka terdahulu yang mengatakan bila keinginan akan terkabul maka harus ada perantara do'a tersebut, hal ini dilakukan dengan meminta pertolongan terhadap makam wali terdahulu yang dianggap memiliki kekuatan yang dapat membantu tercapainya keinginan tersebut. Berikut ini, hal yang dipercayai oleh beberapa masyarakat:

a. Dipercayai dapat memberikan keturunan bagi pasangan suami-istri yang sudah lama menikah tapi belum dikarunia seorang anak.

b. Dipercayai dapat mengobati berbagai jenis penyakit.

c. Dipercayai dapat memberikan ilmu kepada para perantau, agar terlindungi dari berbagai macam bahaya.

d. Dipercayai dapat membantu mempermudah ujian sekolah supaya mendapatkan nilai yang baik, tes masuk perguruan tinggi yang diinginkan.

e. Dipercayai dapat mempermudahkan dalam perihal jodoh.

f. Dan lain-lain.

Adapun tujuan ziarah ke makam Puyang Muara Rambang adalah memohon kepada Allah agar memberkahi para wali terdahulu untuk diampuni segala kesalahannya. Setelah itu barulah mereka memohon agar apa yang menjadi keinginan mereka tersebut terkabulkan. Kepercayaan seperti inilah yang melekat pada masyarakat setempat sehingga pada waktuwaktu mereka sering mengunjungi makam Puyang Muara Rambang tujuannya hanyalah satu, yakni agar keinginan mereka terkabul.

Menurut cerita dari juru kunci makam Puyang Muara Rambang sendiri bahwa beliau sendiri merasakan karamah dari kubur Puyang Muara Rambang sendiri yaitu: Jika para penziarah mengambil sebuah foto bersama makam Puyang Muara Rambang dan hewan peliharaannya maka apabila di cetak foto tersebut tidak akan dapat di cetak dan kertas masih tetap putih bersih. Kemudian jika foto tersebut, diupload di sosial media maka di Desa Lubuk Keliat akan mengalami kebanjiran yang hebat menyebabkan banyak rumah tenggelam dan korban jiwa. Menurut beliau itu adalah salah satu bentuk karamah dari makam Puyang Muara Rambang.

Di sisi lain, menurut itu Putra salah seorang peziarah makam Puyang Muara Rambang yang melakukan ziarah mengaku kadang kala do'anya terpenuhi, tetapi tidak semua keinginan tersebut terkabul, seperti meminta pertolongan dari malapetaka, meminta rezeki, dilancarkan usahanya. Namun setelah beliau melakukan ziarah berulang-ulang akhirnya usaha beliau berjalan sukses dan menjadi usahanya berkembang dari waktu ke waktu, sehingga beliau sengaja menghibahkan kelambu dan berbagai makanan setiap tahun sebagai tanda terima kasih kepada Puyang Muara Rambang. Ketika mereka merasa do'anya terkabulkan maka cerita demi cerita mengenai adanya karamah kubur puyang meyakinkan masyarakat lain yang mendengarkan hal itu. Akibat cerita tersebut maka kepercayaan masyarakat mengenai adanya karamah dari makam Puyang Muara Rambang semakin meningkat sehingga hampir sebagian besar masyarakat telah mempercayai makam Puyang Muara Rambang sebagai makam wali terdahulu yang dianggap memiliki kekuatan dan karamah yang dapat membantu setiap orang yang memakmurkan makam tersebut. Makam Puyang Muara Rambang tersebut dapat dilihat pada Gambar 1 berikut ini:



Gambar 1. Makam Puyang Muara Rambang

Pada saat melakukan kegiatan ziarah kepada makam Puyang Muara Rambang ada beberapa tata cara yang harus dilakukan. Adapun tata cara yang harus dilakukan pada saat berziarah ke makam Puyang Muara Rambang adalah sebagai berikut: 
a. Sebelum berziarahkan ke makam Puyang Muara Rambang, diwajibkan untuk mengambil wudhu terlebih dahulu.

b. Melepaskan alas kaki sebelum masuk ke dalam rumah makam Puyang Muara Rambang.

c. Berperilaku sopan dan ramah ketika mendatangi areal pemakaman Puyang Muara Rambang.

d. Harus membawa persembahan jika ada suatu permohonan kepada Puyang Muara Rambang.

e. Tidak duduk, menginjak-injak, dan tidurtiduran di atas makam Puyang Muara Rambang.

f. Mengucapkan salam kepada Puyang Muara Rambang.

g. Membaca surat yasin untuk Puyang Muara Rambang.

h. Mendoakan dengan ikhlas arwah Puyang Muara Rambang agar bahagia dan tenang di alam kubur.

Di samping itu, dengan berziarah ke makam kita juga akan mengingat sebuah peristiwa yang pasti dialami manusia, yaitu kematian dan hari akhir. Ketika seseorang ingat akan hal itu, setidaknya menjadi cermin untuk meningkatkan amal ibadah kepada Allah SWT. Hidup ini tidak lebih dari mimpi sesaat. Kita akan benar-benar terjaga justru setelah kematian. Tujuannya bukanlah semata-mata memahami makna kehidupan pasca kematian itu, melainkan juga lebih penting lagi memaknai hakikat kehidupan di alam fana. Hal ini berarti bahwa, ziarah ke kuburan akan mengingatkan orang pada kematian.

\section{Nilai Estetika}

Estetika merupakan bagian filsafat atau keindahan. Secara teori estetika sering kali mengambil bentuk penghadiran kondisi keharusan (necessary condition) dan kondisi yang mencukupi (sufficient condition) untuk menunjukan bahwa sesuatu adalah objek, kegiatan, pengalaman, atau suatu estetis. Berkaitan dengan nilai estetika, di daerah sekitar makam Puyang yang dikelilingi berbagai macam pohon, beberapa macam hewan pelihara, dan terdapat aliran sungai. Dengan keindahan lingkungan sekitar sehingga banyak wisatawan berkunjung ke Makam Puyang Muara Rambang untuk melihat makam Puyang Muara Rambang, benda peninggalan Puyang Muara Rambang dan memancing. Keindahan alam sekitar makam Puyang Muara Rambang dapat dilihat pada Gambar 2 berikut ini:

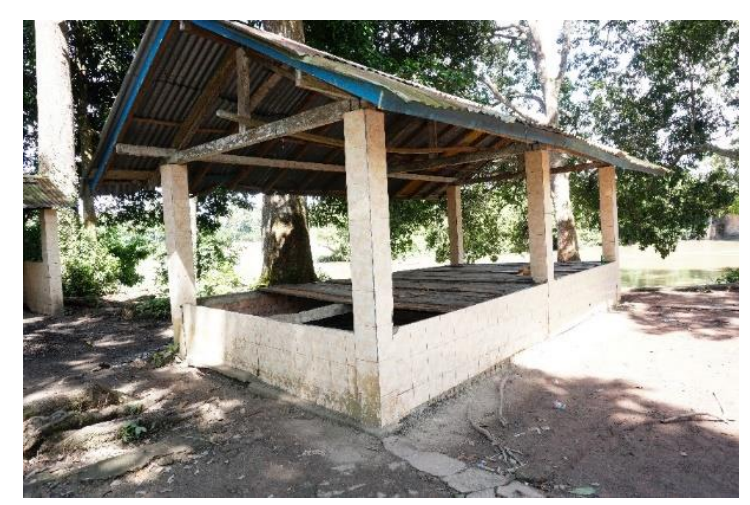

Gambar 2. Keadaan Sekitar Makam Puyang Muara Rambang

\section{Nilai Sosial (Tolong Menolong)}

Tolong menolong dalam bahasa Arabnya adalah ta'awun. Sedangkan menurut istilah, pengertian ta'awun adalah sifat tolong menolong diantaranya sesama manusia dalam hal kebaikan dan takwa. Tolong menolong suatu sifat yang mendorong seseorang untuk membantu dan bekerja sama dengan orang lain. Baik itu teman sejawat, kerabat, organisasi dan lainya. Adanya tolong menolong akan dapat dipelihara kepentingan bersama, kemajuan bangsa dan negara. Jadi, adat ketergantungan pribadi dan masyarakat.

Islam mengikat semua individu dan masyarakat atas dasar persamaan kepentingan. Memperkokoh perasaan saling tolong menolong. Memperteguh kesadaran memikul kewajiban bersama untuk kepentingan bersama. Islam juga menanamkan kesadaran dalam pikiran semua orang bahwa mereka mempunyai tujuan bersama yang tidak mungkin dapat diwujudkan apabila hanya dilakukan oleh seorang, tapi harus diupayakan bersama-sama atas dasar prinsip saling bantu (Qutub, 1987:9).

Tolong menolong merupakan kunci keberhasilan, manusia menurut fitrahnya memerlukan orang lain. Dari lahir manusia memerlukan bantuan orang lain, makan minum, bangun tidur semua memerlukan bantuan orang lain. Oleh karena itu sifat tolong menolong harus 
dipupuk dan disuburkan pada setiap insan (Bakry, 1981:116).

Tolong menolong berarti bekerjasama memperbuat amal yang berguna untuk masyarakat. Kemajuan yang dicapai manusia sekarang dalam semua bidang pada hakekatnya adalah buah dari tolong menolong. Dalam nilai-nilai sejarah Puyang Muara Rambang terkandung nilai tolong menolong, terlihat dalam benda-benda peninggalan Puyang Muara Rambang. Benda tersebut, dapat dilihat pada Gambar 3 dan Gambar 4.

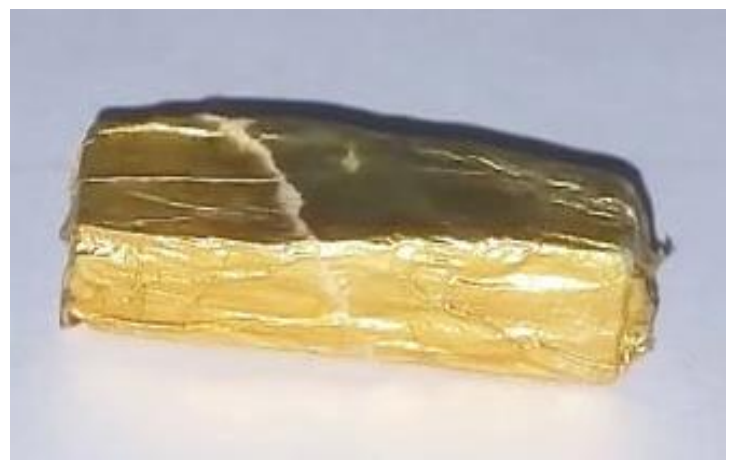

\section{Gambar 3. Peninggalan Puyang Muara Rambang}

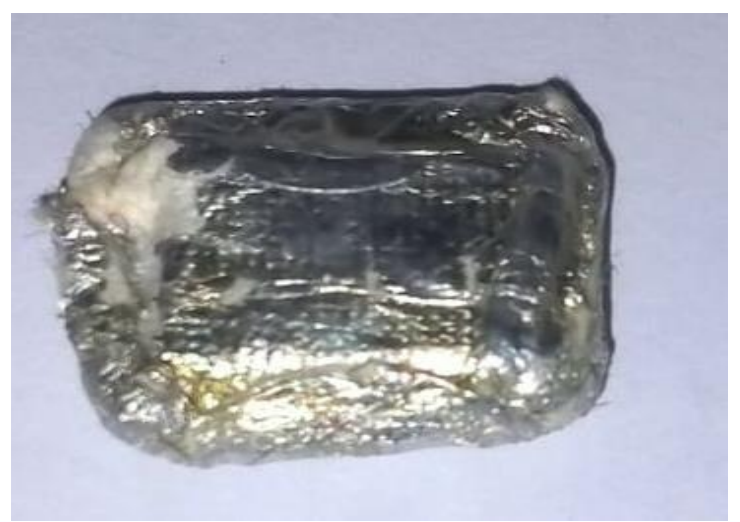

\section{Gambar 4. Peninggalan Puyang Muara Rambang}

Benda-benda yang ada pada Gambar 3 merupakan benda peninggalan dari Puyang Muara Rambang yang dipercayai dapat mengobati berbagai jenis penyakit. Jika memakai benda ini di tubuh dengan cara diikat dengan menggunakan kain bewarna putih laluh dipasang di tubuh. Sedangkan Gambar 4 merupakan benda peninggalan dari Puyang Muara Rambang yang dipercayai dapat memberikan ilmu kepada para perantau, agar terlindungi dari berbagai macam bahaya.
Nilai-nilai sejarah yang terkandung dalam Puyang Muara Rambang yang telah diuraikan dapat dijadikan sebagai sumber belajar sejarah lokal. Nilai-nilai sejarah yang terdapat pada Puyang Muara Rambang terdiri dari beberapa bidang yaitu 1) Bidang ideologi yaitu ajaran agama Islam yang terdapat untuk memiliki tauhid, keimanan dan ketaqwaan terhadap Allah SWT, 2) Bidang politik, bidang ini dicontohkan dari sikap dalam kegiatan tolong-menolong kepada masyarakat sekitar, 3) Sosial budaya, nilai ini memberikan pengajaran kepada peserta didik untuk dapat bekerja sama antar sesama baik peserta didik di sekolah maupun masyarakat luas dengan tetap mematuhi norma-norma yang berlaku dimasyarakat.

Nilai-nilai tersebut banyak bertransformasi dalam diri masyarakat Lubuk Keliat, khususnya para peserta didik di sekolah dan masyarakat di Lubuk Keliat. Hal tersebut menjadi keuntungan bagi dunia pendidikan karena melalui Puyang Muara Rambang dapat digunakan sebagai sumber belajar khususnya mata pelajaran sejarah berbasis lokal. Kondisi ini juga didukung dengan diberlakukanya Kurikulum 2013 yang berorientasi pada keaktifan peserta didik dalam mencari dan memanfaatkan sumber belajar. Terutama berdasarkan analisis silabus dan Kurikulum 2013 di SMA pada mata pelajaran sejarah kelas $X$ kelompok wajib, dengan Kompetensi Inti "Memahami, menerapkan, dan menganalisis pengetahuan faktual, konseptual, prosedural berdasarkan rasa ingin tahunya tentang ilmu pengetahuan, teknologi, seni, budaya, dan humaniora dengan wawasan kemanusiaan, kebangsaan, kenegaraan, dan peradaban terkait fenomena dan kejadian, serta menerapkan pengetahuan prosedural pada bidang kajian yang spesifik sesuai dengan bakat dan minatnya untuk memecahkan masalah", dengan Kompetensi Dasar "Menganalisis berbagai teori tentang proses masuk dan berkembangnya agama dan kebudayaan Islam di Indonesia" dan kelas X kelompok peminatan ilmu sosial dengan Kompetensi Inti "Menghayati dan mengamalkan perilaku jujur, disiplin, tanggung jawab, peduli (gotong royong, kerjasama, toleran, damai), santun, responsif, dan proaktif dan menunjukkan sikap sebagai 
bagian dari solusi atas berbagai permasalahan dalam berinteraksi secara efektif dengan lingkungan sosial dan alam serta dalam menempatkan diri sebagai cerminan bangsa dalam pergaulan dunia". Kompetensi Dasar "Menunjukkan sikap peduli terhadap berbagai hasil budaya zaman nenek moyang". Kurikulum 2013 memberikan peluang bagi sekolah untuk memanfaatkan sumber-sumber belajar yang ada di sekitar lingkungan sekolah, salah satunya memanfaatkan nilai-nilai sejarah Puyang Muara Rambang. Nilai-nilai tersebut juga mengajarkan peserta didik tentang akulturasi dan makna dari sejarah.

\section{SIMPULAN}

Puyang Muara Rambang adalah sosok yang hampir tidak pernah kalah dalam segi apapun (mengalahkan dirinya dan orang lain), kesaktian dan keajaiban yang dimilikinya sangat disegani oleh pengikutnya maupun musuhmusuhnya. Selain itu, Puyang Muara Rambang adalah sosok seorang yang baik hati, bukan hanya kepada manusia tetapi ke makhluk lain juga, seperti hewan dan tumbuh-tumbuhan.
Nilai-nilai sejarah yang terdapat pada Puyang Muara Rambang, adalah: nilai sosial, nilai estetika dan nilai relegius. Dengan dijadikannya rumah limas seratus tiang sebagai sumber pembelajaran sejarah lokal, maka dapat membantu siswa mengetahui sejarah lokal sehingga dapat menumbuhkan rasa nasionalisme dalam diri siswa.

\section{DAFTAR PUSTAKA}

Bakry, O. 1981. Akhlak Muslim. Bandung: Buku Kita.

Kartodirjo, S. 2014. Pendekatan IImu Sosial Dalam Metodologi Sejarah. Yogyakarta: Ombak.

Qutub, S. 1987. Islam dan Perdamaian Dunia. Jakarta: Pustaka Firda.

Soedjatmoko, D. 1995. Historiografi Indonesia: Sebuah Pengantar. Jakarta: Gramedia Pustaka Utama.

Sugiyono. 2005. Memahami Penelitian Kualitatif. Bandung: Alfabeta.

Wasino. 2007. Dari Riset Hingga Tulisan Sejarah. Semarang: Unnes Press. 


\section{KETENTUAN PENULISAN ARTIKEL JURNAL KALPATARU}

1. Naskah berbahasa Indonesia yang disempurnakan bertemakan kesejarah yang meliputi hasil penelitian sejarah, pengajaran sejarah dan penelitian kebudayaan.

2. Naskah harus asli dan belum pernah dimuat dalam media lain. Naskah dapat berupa hasil penelitian/artikel kajian konseptual yang ditulis oleh perorangan dan atau kelompok.

3. Naskah ditulis dengan cara-cara yang sesuai dengan ketentuan penulisan artikel ilmiah menggunakan bahasa Indonesia yang baku, berupa ketikan, beserta soft file dalam CD-RW atau dengan mengirimkan email pada redaksi jurnal Kalpataru dengan alamat jurnalkalpatarusejarah@gmail.com, spasi tunggal, jenis huruf arial narrow ukuran 12, dengan panjang naskah antara 8-15 halaman pada kertas A4.

4. Artikel hasil penelitian memuat:

JUDUL

Nama Penulis

Abstrak

\section{: XXX (HURUF KAPITAL)}

: (disertai jabatan, institusi, dan email)

: (Bahasa Indonesia yang memuat 100-200 kata diikuti kata kunci, dengan jenis huruf arrial narrow dan ukuran huruf 11 serta dicetak miring). masalah penelitian, dan tujuan penelitian).

\section{B. METODE PENELITIAN}
: (memuat latar belakang masalah, tinjauan pustaka secara ringkas,
A. PENDAHULUAN

C. HASIL DAN PEMBAHASAN

D. SIMPULAN

: (berisi simpulan).

DAFTAR PUSTAKA : : (berisi pustaka yang dirujuk dalam uraian naskah).

5. Artikel Kajian Konseptual memuat:
JUDUL
: XXX (HURUF KAPITAL)
Nama Penulis
Abstrak
: (disertai jabatan, institusi, dan email)
: (Bahasa Indonesia yang memuat 100-200 kata diikuti kata kunci, dengan jenis huruf arrial narrow dan ukuran huruf 11 serta dicetak miring.
PENDAHULUAN
: (memuat latar belakang masalah, tinjauan pustaka secara ringkas, masalah penelitian, dan tujuan penelitian).
Sub Judul
: Sesuai dengan kebutuhan (tanpa numbering).
Simpulan
DAFTAR PUSTAKA
: (berisi simpulan dan saran).

6. Referensi sumber dalam teks artikel ditulis dengan menggunakan side note, contoh (Jalaludin, 1991:79); sementara penulisan daftar pustaka disusun dengan ketentuan. Nama pengarang. Tahun terbit. Judul (dicetak miring). Kota terbit: Nama Penerbit. Contoh: Koentjaraningrat. 2010. Manusia dan Kebudayaan di Indonesia. Jakarta: Djambatan. Daftar pustaka hanya memuat pustaka/sumber yang dirujuk dalam uraian dan disusun menurut abjad tanpa nomor urut.

7. Naskah yang dimuat akan disunting kembali oleh redaksi tanpa mengubah isinya.

8. Naskah yang ditolak (tidak bisa dimuat) akan dikirim kembali ke penulis dengan pemberitahuan tertulis dari redaksi atau melalui email.

9. Penulis yang naskahnya dimuat akan mendapat 1 (satu) majalah nomor yang bersangkutan.

10. Kontak person: Muhamad Idris (081271498618); Eva Dina Chairunisa (082281267851); Jeki Sepriady (085269261780). 